\title{
Violência de Estado e de gênero em três contos de Bernardo Kucinski
}

\author{
State and Gender Violence in Three Short Stories by Bernardo Kucinski \\ Violencia de Estado y de género en tres cuentos de Bernardo Kucinski
}

Leandra Postay*

\section{Resumo}

O presente trabalho se propõe a analisar os contos "Sobre a natureza do homem", "Você vai voltar pra mim" e "Recordações do casarão", todos contidos no livro Você vai voltar pra mim e outros contos (2014a), de Bernardo Kucinski. Os textos selecionados têm como temática central experiências vinculadas à ditadura militar no Brasil e serão analisados sob a hipótese de que, em seus enredos, há um vínculo entre violência de Estado e violência de gênero. A análise tem como base a compreensão de que os contos de Kucinski possuem um teor testemunhal, ou seja, há uma implicação do conteúdo histórico sobre o conteúdo literário. A partir de tal recorte e da leitura empreendida, é possível concluir que a violência do Brasil ditatorial manifestou uma face patriarcal e que a literatura é um espaço frutífero à elaboração e reflexão sobre a barbárie.

Palavras-chave: literatura contemporânea, literatura e violência, literatura e história.

\begin{abstract}
This paper aims to analyze the short stories "Sobre a natureza do homem", "Você vai voltar pra mim" and "Recordações do casarão", published in Você vai voltar pra mim (2014a), by Bernardo Kucinski. The texts narrate events which occurred during the Brazilian military dictatorship, and this study hypothesizes that the plots contain an entanglement between state violence and gender-based violence. The interpretation is based on the perception that Kucinski's short stories are manifestations of testimonial literature, that is, they establish a connection between historical context and literary content. From this perspective, it is possible to understand that, during the dictatorship in Brazil, the violence had a patriarchal face, and that literature is a powerful way to criticize the barbarism.
\end{abstract}

Keywords: contemporary literature, literature and violence, literature and history.

\section{Resumen}

Este artículo propone el análisis de los cuentos "Sobre a natureza do homem", "Você vai voltar pra mim" y "Recordações do casarão", todos publicados en el libro "Você vai voltar pra mim" (2014a), del autor Bernardo Kucinski. Los textos seleccionados tienen como temática central las experiencias conectadas a la dictadura militar en el Brasil y van a ser analizados desde la hipótesis de que, en sus tramas, hay un entrelazamiento entre la violencia del Estado y la violencia de género. El análisis tiene como base la visión de que los cuentos de Kucinski pueden ser leídos como literatura de testimonio, o sea, hay una relación estricta entre el contenido histórico y el contenido literario. Con esta lectura, es posible concluir que la violencia del Brasil militarizado tenía también rasgos patriarcales y que la literatura es un importante espacio para la reflexión acerca de la barbarie.

Palabras-clave: literatura contemporánea, literatura y violência, literatura y historia.

Este artigo se propõe a analisar os contos "Sobre a natureza do homem", "Você vai voltar pra mim" e "Recordações do casarão", publicados em Você vai voltar pra mim e outros contos (2014a), de Bernardo Kucinski. A publicação possui uma espécie de prólogo, assinado pelo autor, que informa o leitor a respeito do contexto histórico a que as narrativas ali reunidas remetem:

\footnotetext{
*Universidade de São Paulo (USP), São Paulo, SP, Brasil. (Dorcid.org/0000-0002-6569-0175. E-mail: leandra.postay @ hotmail.com
} 
As histórias desta coletânea fazem parte de um conjunto de 150 contos escritos entre junho de 2010 e junho de 2013, dos quais foram selecionados aqueles que se inspiram no clima de opressão reinante no nosso país nas décadas de 1960 e 1970 e suas sequelas. Aos leitores familiarizados com aqueles tempos, os contos podem lembrar episódios e pessoas conhecidas. Mas não passam de invenções, criações literárias sem nenhuma obrigação de fidelidade a pessoas ou fatos que eventualmente os possam ter inspirado. Aos leitores mais jovens, não familiarizados com aqueles tempos, acredito que essas narrativas de cunho literário permitirão sentir um pouco a atmosfera de então, com nuances e complexidades que a simples história factual não conseguiria captar (Kucinski, 2014a, p. 7).

As décadas de 1960 e 1970 abrangem "o mais duro período da mais duradoura das ditaduras nacionais" (Gaspari, 2011, p. 13), período que compreende, especificamente, o intervalo entre o ano de 1969, quando foi imposto o Ato Institucional número 5, e o ano de 1974, marcado pelo extermínio da guerrilha empreendida pelo Partido Comunista na região do Araguaia. Há, portanto, nos contos de Kucinski, pontos de contato com a chamada realidade histórica. É parte fundamental da composição das narrativas o cenário de ditadura militar em que se desenvolvem ou que rememoram. Simultaneamente, entretanto, o escritor enfatiza a natureza fictícia da obra: "os contos [...] não passam de invenções, criações literárias sem nenhuma obrigação de fidelidade". Vale recuperar as palavras de Joachim Michael sobre o romance $K$. Relato de uma busca, também de Kucinski, cuja advertência inicial possui uma estrutura semelhante ao prólogo aqui estudado: ${ }^{1}$

O que sucedeu está em suspenso - se invoca, mas não se reproduz. Não se rompe com o real, mas se altera sua validade. Insiste-se nos acontecimentos da época e ao mesmo tempo submetem-se os fatos a um estranhamento no qual perdem sua autoridade imediata. Predomina, em outras palavras, a ficção, mas evidentemente ela nunca se desprende da realidade. É como se a ficção estendesse a pertinência do real para além de seu âmbito. Nesse caso, invoca-se uma noção de realidade que não se circunscreve aos fatos (2017, p. 21).

Os contos selecionados para análise, desse modo, não se configuram como imediatamente referenciais, no entanto, o panorama histórico que lhes é comum e, como veremos, coincidências entre os textos literários e alguns registros documentais permitem entender que se aproximam do testemunho.

A literatura de testemunho tem suas origens na produção de sobreviventes dos campos de concentração nazistas que fizeram da experiência de barbárie tema central em sua prosa e em seus versos. A vertente latino-americana da literatura testemunhal, estabelecida anos após o fim da Segunda Grande Guerra, não está relacionada a um governo totalitário, mas possui igualmente uma importante faceta política e social. Ela nasceu a partir dos regimes ditatoriais que se espalharam pelo sul do continente. De acordo com Valeria de Marco, em "A literatura de testemunho e a violência de Estado", a noção de Testimonio, como ficou conhecida a literatura de testemunho escrita em castelhano, surgiu como categoria do Prêmio Casa das Américas, em 1970 (Marco, 2004, p. 46), como consequência da proliferação de textos que abordavam a temática da violência empreendida pelo governo contra a sociedade e que eram escritos com base em experiências reais. Também a conjuntura brasileira, principalmente durante a ditadura militar, fomentou uma produção portadora de tais características. As obras identificadas como testemunhais apresentam premissas para além da elaboração estética. Segundo Jaime Ginzburg:

Críticos dedicados a Levi, Menchú, Mendes e Pepetela têm em comum, ao falar em testemunho, uma perspectiva que associa diretamente o debate sobre a escrita à reflexão sobre exclusão social. [...] O estudo do testemunho articula estética e ética como campos indissociáveis de pensamento (2012, p. 52).

As narrativas de Kucinski selecionadas serão analisadas a partir da consideração do contexto histórico que as une, assim como da articulação entre estética e ética observada por Ginzburg, relativa ao testemunho. Assumiremos a hipótese de que a violência direcionada à mulher,

\footnotetext{
1 “Caro leitor: Tudo neste livro é invenção, mas quase tudo aconteceu” (Kucinski, 2014e, p. 8).
} 
mesmo quando motivada a princípio por uma política de Estado autoritária e repressora, raramente deixa de ser também violência de gênero. Sob tal perspectiva, verificaremos de que forma essa violência de Estado é percebida e recebida pelos personagens masculinos e femininos que viveram na clandestinidade, refletindo sobre possíveis convergências e divergências e o que elas podem significar em termos literários e históricos.

O conto "Você vai voltar pra mim" (Kucinski, 2014b), homônimo ao livro, apresenta ambiguidade em seu título. Um leitor desavisado acerca da temática principal da publicação poderia presumir algo de amor romântico na afirmação "você vai voltar pra mim", que funcionaria bem como mote de tramas populares da indústria cultural em que um casal de amantes passa por adversidades que os separam, restando a esperança do reencontro, que normalmente se efetiva. O texto de Kucinski, contudo, inicia-se com uma fala que desfaz a ambiguidade: “- Veja bem o que você vai dizer, não esqueça que depois você volta pra cá; você volta pra mim - ele repetiu" (Kucinski, 2014b, p. 69). A despeito da ausência de informações, nesse primeiro momento, quanto a quem seriam "ele" e seu interlocutor, o tom de ameaça, e não de romance, está bem marcado em "veja bem o que você vai dizer", seguido do igualmente imperativo "não esqueça". As duas sentenças funcionam de maneira articulada: "cuidado com o que você vai dizer, porque você vai voltar pra mim e, dependendo do que disser, haverá consequências". O restante do conto esclarece que o enunciador é um militar, torturador da presa política a quem se dirige. Ela está prestes a ser julgada em um tribunal para o qual é conduzida em um camburão:

Era a primeira audiência do seu processo. Depois que foi marcada, não penduraram mais, deixaram entrar comida, pomadas, roupa. Hoje está de blusa nova, saia também. Todos a querem bem-apresentada. Ia dar tudo certo, garantiram. Só precisava manter o controle. Não dizer nada, apenas negar as acusações do indiciamento. Ficar nisso. Estava só ela no camburão. Só ela, de tantos companheiros, ainda viva e indo para uma audiência na Justiça Militar. Se não fosse aquela notícia da sua prisão, já estava morta (Kucinski, 2014b, p. 69).

Há muitas lacunas no excerto acima: não fica claro quem são esses que não a penduraram mais, em referência à interrupção da tortura; quem são todos que "a querem bem-apresentada"; quem são os que garantiram que "ia dar tudo certo". Também não se sabe se foram esses últimos que asseguraram que ela "só precisava manter o controle. Não dizer nada" (de certo modo, em coro com o torturador), se são conselhos que a moça dá a si mesma ou apenas constatações do narrador. Esses espaços referenciais não preenchidos simulam as lacunas próprias do momento vivido pela personagem: apesar da garantia de que tudo daria certo, não havia garantia nenhuma. Sendo a moça uma presa política em tempos de ditadura militar, tempos de retirada de direitos, suas garantias estão suspensas, mesmo com a excepcionalidade de uma audiência, cuja motivação possivelmente se associa à imprensa ("Se não fosse aquela notícia da sua prisão, já estava morta"). O narrador pontua que a regra para os que acabavam nos porões da ditadura era a morte ("Só ela, de tantos companheiros, ainda viva"). Em $A$ ditadura escancarada, lemos: "Entre 1964 e 1968 foram 308 as denúncias de torturas apresentadas por presos políticos às cortes militares. Durante o ano de 1969 elas somaram 1.027, e em 70, 1.206" (Gaspari, 2011, p. 159). Ser exceção entre 308, 1.027 ou 1.206 apenas enfatiza a gravidade da regra. A situação de desamparo em que a personagem se encontra é reforçada pela denominação quase paradoxal da instituição responsável por sua audiência: "Justiça Militar". A independência esperada em um Estado democrático entre os poderes Executivo e Judiciário aqui não apenas se faz ausente, como sua ausência sequer é mascarada: aqueles que julgarão a ré são os mesmos que condenam, sem possibilidade de julgamento, que empreendem a tortura, utilizando-a para conseguir que o sujeito produza provas contra si mesmo. Essa última conjuntura também está posta no conto:

A audiência foi curta. Um coronel leu o indiciamento. Ela se declarou inocente de todas as acusações, menos da guarida ao estudante, por dever humanitário, não tinha nada a ver com o que ele fazia. Respondeu como o advogado havia recomendado. $\mathrm{O}$ juiz auditor a interrompeu.

- Não é o que está na confissão que a senhora assinou, tomada a termo pelo delegado. 
Foi então que ela perdeu o controle e gritou:

- Assinei sob tortura! Esse delegado filho da puta me pendurou sete vezes (Kucinski, 2014b, p. 70).

O depoimento da ré contradiz uma declaração anterior, por ela mesma assinada. A palavra não vale tanto quanto o documento, o que faz com que a mulher seja questionada e "perca o controle", contrarie as recomendações do advogado, ou seja, diga a verdade, exponha a situação que o tribunal militar conhece, mas pretende ocultar: ela foi torturada e, sob tortura, produziu as provas necessárias para sua condenação. Em Brasil: nunca mais, livro organizado por D. Paulo Evaristo Arns que traz relatos de diversas vítimas da ditadura, está registrado:

Devido às torturas aplicadas aos réus na fase do inquérito policial, muitos revelaram à Justiça Militar a falsidade de seus depoimentos, feitos com o objetivo de fazer cessar a violência que se abatia sobre eles. Ouvido em São Paulo, em 1972, narrou o jornalista Renato Leone Mohor, de 30 anos: [...] que, certa noite, ouviu gritos de mulher e choros de criança intercalados com música e lhe foi dito que eram a sua esposa e filha que estavam sendo torturadas; que, assim, o interrogado pediu que dessem liberdade à esposa e filha e que responderia a todas as perguntas da forma que eles quisessem, chegando mesmo a inventar uma porção de coisas que ficou constando em suas declarações (1985, p. 211-212).

A situação construída ficcionalmente por Kucinski, portanto, encontra correspondência no testemunho de vítimas dos anos de chumbo, e sua recorrência é um dos indícios da institucionalização da tortura em tal período. Ela não apenas era empreendida sistematicamente com amplo conhecimento das autoridades, como também ensinada, como componente curricular, na Polícia do Exército (Arns, 1985, p. 31). Ademais, torturadores passaram a ser premiados por seus serviços com a Medalha do Pacificador, uma condecoração oficial (Gaspari, 2011, p. 22). A tortura, percebe-se, não era um "último recurso" ou uma ferramenta utilizada de maneira fortuita por agentes militares isolados e particularmente cruéis, ela se constituiu como estratégia de Estado regular e difundida. Diante da larga escala da prática e do conhecimento de parcela da sociedade a seu respeito, como entender o que se passa após a colocação da personagem de que assinou a declaração sob tortura e de que foi "pendurada" pelo delegado sete vezes?

Faz-se um silêncio estranho. Sete vezes, sete vezes, as palavras pareciam dar a volta na sala do tribunal. Sete vezes, nem uma nem duas, sete vezes. O juiz suspendeu a sessão e convocou todos à sua sala (Kucinski, 2014b, p. 70).

O silêncio estranho como resposta à declaração é resultado de uma realidade em que a tortura é institucionalizada, mas velada. Repetidamente, tem-se que a mulher não deve falar nada, espera-se que ela não fale nada, pois a própria acusada está consciente de que tem mais chances de liberdade ocultando a violência estatal. Ela não só não cala, como enfatiza a tortura ("me pendurou sete vezes") e a pessoaliza, indicando seu agente ("esse delegado filho da puta"). As palavras que, paradoxalmente, em meio ao silêncio dão a volta no tribunal ecoam também no trecho transcrito, "Sete vezes, sete vezes [...]. Sete vezes, nem uma nem duas, sete vezes", indicando a ressonância afetiva nos presentes do impacto de tal declaração, assim como a possibilidade da presença firme mesmo do não dito.

A sessão é suspensa, mas, de certo modo, continua, extraoficialmente, no gabinete no juiz:

No recesso do gabinete, ela disse tudo. Não conseguiu parar de falar. Mostrou os hematomas nos braços e nos tornozelos, falou das palmadas, dos choques nos seios e na vagina, da ameaça de estupro, da simulação de fuzilamento, dos afogamentos, dos onze dias na solitária. Por fim, falou da advertência do torturador. Disse que para lá não voltava, preferia morrer. Se a levarem de volta se mata, se atira pela primeira janela; se não tiver janela, se mata batendo a cabeça na parede; se não tiver parede, corta os pulsos; se não tiver com que cortar; morde com os dentes; se não der certo, faz greve de fome até morrer (Kucinski, 2014b, p. 70).

Ao dizer tudo, ao contrário do que lhe tinha sido aconselhado, e mostrar os hematomas, a personagem procura confirmar a afirmação anterior: "Assinei sob tortura". As marcas em seu corpo são contraprova à declaração por ela assinada, cujo conteúdo foi negado no início da audiência. Usar o corpo como prova do que é dito é um gesto de denúncia necessário no 
contexto em que a ré reconhece que o sistema judiciário é parcial contra ela. Quando fala da advertência do torturador, frisando por meio de uma enumeração imprecisa que prefere a morte, ela indica que sabe que voltar para o Departamento de Ordem Política e Social (Dops) é voltar para a tortura, para a desumanização, à qual é preferível a morte. Diante dos apelos, é assegurado à moça, inclusive por meio de uma documentação, que ela seria transferida para o presídio feminino. Contudo, o desfecho ocorre da seguinte maneira:

De novo está só no camburão. Percebe que é o mesmo que a trouxe e se inquieta. Passa a observar o trajeto pela grade de ventilação. Vê, aterrorizada, entrarem pelo mesmo portão através do qual haviam saído para o tribunal. $\mathrm{O}$ camburão para, a porta se abre. $\mathrm{O}$ torturador diz, sorrindo:

- Eu disse que você ia voltar pra mim, não disse? Vem, benzinho, vamos brincar um pouco.

Ele a agarra pelas canelas e a arrasta para fora. Os outros em volta riem (Kucinski, 2014b, p. 71).

Esse final, junto à afirmação anterior de que um depoimento fora assinado sob tortura, evidencia a falsidade de documentos governamentais, que, além de serem utilizados de maneira ilegítima como ferramenta de controle da máquina administrativa, contribuem com a construção da história oficial, silenciando mais uma vez aqueles que foram colocados no banco dos réus e nas celas do Dops. Para além de sua importância como alternativa histórica, a narrativa de Kucinski tem como particular ponto de interesse, para este estudo, o vocabulário utilizado ao final, ameaçador como no início, pelo torturador da personagem.

À ambiguidade da sentença "você vai voltar pra mim", que sustenta ares românticos, somam-se o vocativo "benzinho" e o verbo "brincar". O homem recorre, de maneira irônica, a um léxico próprio do campo afetivo para anunciar a violência ao corpo da mulher. A personagem dessa história é singular, ela anuncia no tribunal uma situação que, se calada, provavelmente lhe asseguraria a vida e a liberdade, mas, ao mesmo tempo, ela representa as tantas vítimas da ditadura e, por isso, dá visibilidade a esse grupo. Todavia, para além de ser uma integrante de tal grupo, ela é uma mulher vítima da ditadura diante de um torturador homem. Esse sujeito marca a diferença de gênero ao chamá-la de "benzinho" e ao se referir seja à tortura de maneira geral, seja à violência sexual como "brincadeira". Seria difícil imaginar as mesmas palavras sendo proferidas a um homem, ainda que se tratasse do mesmo modo de um preso político. No gabinete do juiz, a moça relata as ameaças de estupro, violentação que, conforme relatos de sobreviventes, de fato não era rara:

$\mathrm{O}$ sistema repressivo não fez distinção entre homens e mulheres. O que variou foi a forma de tortura. Além das naturais diferenças sexuais da mulher, uma eventual gravidez a torna especialmente vulnerável. Por serem do sexo masculino, os torturadores fizeram da sexualidade feminina objeto especial de suas taras (Arns, 1985, p. 46).

É preciso repensar a afirmação de que "o sistema repressivo não fez distinção entre homens e mulheres". Não fez distinção no sentido de que homens e mulheres eram perseguidos, presos, torturados, mortos. No entanto, se mulheres, diferente de homens, podendo estar grávidas, sofriam aborto durante as sessões de tortura e se, por serem os torturadores do sexo masculino, mulheres eram frequentemente assediadas e estupradas, então havia, sim, distinção entre homens e mulheres. A violência de Estado atingia tanto homens quanto mulheres, mas, contra estas, essa mesma violência assumia (como assume, nos mais diferentes cenários) frequentemente também a forma de violência de gênero. Em Language and body, Veena Das descreve uma cena da literatura indiana dotada de um esforço por expressar a dor, que, segundo a autora, requer uma linguagem própria, muitas vezes alcançada apenas ficcionalmente:

A mulher traça desenhos grotescos em seu corpo, registrando-os apenas no espelho. Ela diz que está desenhando um corpo adequado para a época: naquele tempo, ela diz, as mulheres tinham que ter duas barrigas - uma era a normal, e a segunda era para que pudessem carregar os frutos da violência dentro si (Das, 2007, p. 55, tradução nossa). 
O artigo de Veena Das trata dos conflitos indianos pós-coloniais, ou seja, de uma realidade geográfica e temporalmente distante do Brasil ditatorial. Entretanto, nos interessa especialmente aqui a imagem de um corpo feminino adaptado para a violência: "naquele tempo, ela diz, as mulheres tinham que ter duas barrigas". Está marcado que as mulheres têm a necessidade de duas barrigas, não todos os seres humanos atingidos pela violência, o que sugere que homens e mulheres não são atingidos da mesma forma. A mulher não clama pelo fim da violência, mas por uma estrutura anatômica capaz de carregar os frutos da violência, como se não fosse sequer possível pensar em uma realidade pacífica e na inexistência dos referidos frutos. Ou seja, pesa a essa mulher não apenas a violação do corpo em si, mas também o que resulta desse gesto de agressão e invasão do corpo. Os contos seguintes de Kucinski a serem analisados são espaço privilegiado para se pensar em tais frutos.

"Sobre a natureza do homem" se passa em um tempo posterior à ditadura, quando antigos presos políticos estão sendo indenizados pelo governo pelos abusos cometidos. O conto é narrado em primeira pessoa por Rui, que liga para uma antiga colega de faculdade, Maria Imaculata, confinada à época do militarismo no mesmo presídio que ele, para alertá-la de que o prazo para solicitação da indenização está acabando. O telefone é atendido por uma mulher que informa que aquela por quem o homem procura está muito doente e não fala ao telefone, solicita um número de contato e avisa que um advogado irá entrar em contato. A tarde que antecede a reunião com o advogado, Eliseu Rezende, é marcada por lembranças:

A imagem de Imaculata permaneceu indo e vindo, como um luminoso piscando na minha retina. Maria Imaculata, delicada, miudinha, cabelos louros encaracolados, óculos de aros finos, fala suave, sempre alegre e disponível para meia hora de conversa; pelo menos era assim comigo, ali mesmo, no pátio da faculdade. Lembrei-me de súbito daquela tarde, quanto ficamos até quase o anoitecer. Eu não deveria conversar com ela regularmente, essas eram as regras de segurança; ela era uma simples simpatizante, ajudava em tarefas leves, eu sabia disso, ela é que não sabia que eu também pertencia à organização. Eu era de um grupo de ação armada, não deveria conversar à toa com ela. Falávamos de cinema, literatura, filosofia. A última aula era de filosofia, e quase sempre a conversa começava pelo tema da aula. Lembro que naquela tarde o papo foi sobre a natureza do ser humano. O homem nasce bom e se torna malvado com o tempo ou já nasce com maus instintos? É o homem de Hobbes ou de Rousseau? Havia muita empatia entre nós. Naquela tarde ela já estava sendo observada. Eles não sabiam quem eu era, mas nos fotografaram conversando (Kucinski, 2014c, p. 44-45).

Naquele mesmo dia, Imaculata foi presa e "a torturaram incessantemente". O narrador, preso seis meses depois, conta que a reencontrou na cadeia, "muito machucada. Ela passava horas imóvel, sentada, de olhos fixos na parede à sua frente. [...] Assim permaneceu por três anos, parecendo embotada, sem reagir a nada, sem demonstrar afeto, desgosto ou o que fosse" (Kucinski, 2014c, p. 45-46). A descrição do estado da moça após a prisão e a tortura contrasta com a jovem apresentada como "sempre alegre e disponível para meia hora de conversa", a mudança brusca de comportamento sinaliza que as cicatrizes deixadas pela violação do corpo ultrapassam o nível físico. Ao encontrar o advogado, Rui fica sabendo que Imaculata nunca se recompôs:

Logo que ela saiu da prisão, recuperou um pouco de vivacidade [...]. Até que um dia ela se apagou por completo [...]. Tiveram que alimentá-la a força. Mas ela urinava e defecava na própria roupa. E por duas vezes entrou em convulsão. Decidiram interná-la para tratamento. Estava sofrendo de um transtorno psíquico muito severo e perigoso (Kucinski, 2014c, p. 48).

O narrador não fala com detalhes a respeito de sua própria estada na prisão. Não é possível saber se também ele foi torturado, mas chama atenção o contraste de sua postura ativa e sua capacidade de organização da linguagem para elaboração de uma narrativa sobre os fatos passados em relação ao estado dependente e abúlico de Imaculata. Não seria produtivo aqui estabelecer uma hierarquia entre as marcas deixadas em um e em outro pelo mesmo sistema repressivo, mas partir das diferenças para entender o que há de específico no caso da moça. Eliseu relata que "Nas duas primeiras semanas, Maria Imaculata foi muito torturada. A equipe que a interrogava foi de uma selvageria sem limites. Depois a trancaram numa solitária" (Kucinski, 2014c, p. 47). Há na fala do advogado uma intensificação das agressões aplicadas. 
Qualquer ato de tortura já se configura como "uma selvageria sem limites". A redundância enfatiza que, mesmo no território desumano e extraordinário da tortura, o que sua cliente sofreu foi particularmente desumano e extraordinário. Ela não foi apenas (como se esse advérbio aqui coubesse) torturada, ela foi muito torturada. Toda experiência de tortura contém a potência de se converter em trauma. No caso de Imaculata, é como se a intensidade do trauma se manifestasse de maneira proporcional a essa desmedida do que já não tem medida ("a tortura em excesso"). Beatriz de Moraes Vieira escreve:

Derivado do termo grego para designar "ferida", o trauma pode ser compreendido como o desdobramento de um sofrimento desmedido para quem o viveu, gerando uma desorganização psíquica que viola a capacidade de enfrentamento e domínio prático e simbólico da experiência dolorosa. Produz-se, por isso, um certo "apagamento" da dinâmica mental que permitiria a elaboração "cicatrizante", por assim dizer, reduzindo então o poder de ordenar, estabelecer ligações, suportar afetos e representar o acontecido, seja pela memória ou expressão. [...] Em outras palavras, as ocorrências catastróficas podem provocar grandes desarranjos psíquicos, interferindo no processo de subjetivação dos indivíduos, uma vez que desencadeiam um transbordamento de afetos e intensidades que não comportam sentido entre si (2010, p. 154).

Diante da impossibilidade de cicatrização, Imaculata "apaga”, seu desarranjo psíquico é, de certa maneira, escudo diante da realidade que a vítima de extrema violência não encontra meios de elaborar, à qual não consegue conferir sentido. A ré de "Você vai voltar pra mim", que, diferente de Imaculata, consegue se comunicar, relata as ameaças de estupro que sofreu durante a tortura. Pensando na realidade de então, não é improvável que a personagem de "A natureza do homem", atingida por "selvagerias sem limites", tenha sido abusada sexualmente. As violações sofridas não são explicitadas no texto, mas foram suficientes para deixar sua vítima na degradante situação exposta. Contudo, o advogado afirma que "Depois [que ela saiu da prisão] foi pior" (Kucinski, 2014c, p. 47, grifo nosso). Após ser internada em um hospital psiquiátrico do SUS no Jardim Botânico:

Imaculata foi violentada repetidas vezes por dois pacientes. Eles se revezavam. Um a agarrava e tapava sua boca, o outro a estuprava. Isso durou meses. Ela não conseguia dizer nada, ficava em estado catatônico. Até que engravidou. Só então descobriram o que estava acontecendo. Quando a criança nasceu, um menino, ela sofreu um novo transtorno de personalidade [...]. Os pais levaram o neto para casa [...]. Hoje ela se medica com antipsicóticos, vive com os pais, embora sem nenhuma atividade, desligada do mundo (Kucinski, 2014c, p. 48).

Nesse ponto da história, parece ressoar o título, "A natureza do homem", que encontra correspondência e também dissonância na conversa da juventude entre os dois personagens que falavam sobre a noção da "natureza do ser humano" discutida na aula de filosofia. Por mais que o senso comum utilize frequentemente o substantivo "homem" como sinônimo de "humanidade", não se deve tomar como irrelevante a substituição no título de "ser humano" por "homem". O fato de a mesma expressão aparecer duas vezes em formatos diferentes indica que essa distinção é significativa. O trecho acima transcrito é a expressão por excelência, no conto, da natureza do homem, do ser humano do sexo masculino: Imaculata, já atingida por uma situação de extrema violência e dor, passa por outra. No espaço em que deveria estar recebendo cuidado, é estuprada sistematicamente por dois outros pacientes, dois homens. Os traumas decorrentes da tortura e da violência sexual já se configuram como frutos da violência (retomando a imagem da personagem descrita por Veena Das), mas nasce ainda outro fruto dessa situação: um filho.

Quanto a isso, vale pontuar que também a negligência do Estado, responsável pela instituição psiquiátrica, representa uma violência (simbólica). ${ }^{2}$ A violência sexual, assim como sua prática continuada, foi facilitada porque, no espaço em que deveria estar sendo cuidada, a mulher encontrava-se, na verdade, desassistida. O absurdo dessa situação de descaso é reforçado pelo fato de os abusos só serem descobertos por causa da gravidez. Desse modo, o trauma que ali supostamente seria tratado na verdade se agrava. O mesmo Estado que, por

\footnotetext{
${ }^{2}$ Os conceitos de violência física e violência simbólica são desenvolvidos por Pierre Bourdieu em A dominação masculina (2014, p. 54-65).
} 
excesso de presença e controle, feriu Imaculata nos anos de ditadura permite, por ausência, que ela seja novamente ferida.

A criança que nasce é um menino. Rui pergunta sobre ele, e o advogado responde:

- O garoto está com quatro anos, é esperto, diz que a mãe ficou doente por causa de uns homens do mal que a maltrataram e que quando crescer vai comprar uma espada bem grande e matar todos eles (p. 48).

Essa fala é mais uma ilustração da "natureza do homem". O fruto do ventre dessa Maria Imaculata, que ironicamente de imaculada nada tem, vingará os pecados do mundo com a mesma arma que lhe gerou: a violência. $O$ desfecho do conto é anunciação da continuidade dos padrões de barbárie da sociedade. Isso se dá porque, como afirma Jaime Ginzburg em Literatura, violência e melancolia (2013, p. 24), a sociedade brasileira, herdeira e integrante da ocidental, é constituída violentamente. A compreensão da violência como inerente à humanidade é resultado de um processo histórico que naturaliza parâmetros opressores. Portanto, a "natureza do homem" não é, ao contrário do que o léxico poderia sugerir, biológica. Não nos interessa reforçar uma visão determinista que relativiza a responsabilidade de criminosos sexuais do sexo masculino ao propor que estes agiriam por instinto. A natureza do homem é, na verdade, desdobramento da manutenção de estruturas de dominação históricas, com a qual contribuem, conforme Bourdieu, os homens, "com suas armas como a violência física e a violência simbólica", ao lado de instituições, como a Igreja e o Estado (2014, p. 55-56).

O relato quanto à vida de Imaculata potencializa o estranhamento frente ao início do conto "Recordações do casarão" (Kucinski, 2014d, p. 111):

- Você diz que foram os melhores anos da tua vida... pra mim foram os piores.

- É que eu nunca trepei tanto, nem antes nem depois.

A narrativa é formada majoritariamente pelo diálogo entre dois homens que moravam no mesmo casarão à época da ditadura. A propriedade era uma espécie de república de militantes de esquerda, que viviam na clandestinidade. Os personagens, que não se viam há vinte anos, sentam-se no bar e começam a recuperar histórias e impressões daqueles tempos. A partir das questões expostas nos contos anteriormente analisados, o efeito decorrente da leitura de que para alguém, contrário ao governo ditatorial, os anos de chumbo possam ter sido os melhores da vida é de choque. Esse personagem pontua ao longo da conversa: "começamos o ritual da pinguinha e do baseado. É por essas que eu digo que foram os melhores anos da minha vida"; "o que interessava mesmo era a curtição" (Kucinski, 2014d, p. 116). Em resposta à saudade que seu interlocutor diz ter das discussões políticas, o homem observa que é das "trepadas" que mais sente falta e recorda uma noite em que fizeram "uma puta festa [...]. Enchemos a cara, foi um desbunde" (Kucinski, 2014d, p. 119, p. 121).

Além das memórias festivas, chama a atenção o modo como as mulheres são apresentadas nas recordações: Brenda era "uma ingênua", "puta mulher", "bonita demais", com um "corpo de Vênus de Milo"; Dolores era uma "argentina desesperada", "muito gostosa"; a filha de Dolores, uma criança, é chamada de "histérica"; Bia era "mulher forte", "gostosa", "boa de cama", "liberada", tinha "corpo de violão"; Inês era "muito louca"; Vivian era "uma loirona encorpada" (Kucinski, 2014d, p. 113-119). De modo geral, mesmo quando figuram em episódios relevantes politicamente, as mulheres ou são associadas a estereótipos advindos da psicanálise e tipicamente relacionados ao feminino ("histérica", "muito louca") ou têm seus corpos objetificados, como se fossem antes de tudo instrumentos sexuais para o desfrute masculino. É um dos personagens em especial (o mesmo para quem os anos da ditadura foram os melhores) quem usa esse vocabulário e, em certos momentos, o outro o questiona, como em:

- Mulher forte, a Bia.

- E gostosa. Corpo de violão. Boa de cama, liberada.

- Você fala como se ela fosse promíscua.

- Nada disso, maior respeito (Kucinski, 2014d, p. 116).

Parece haver uma espécie de crítica ao discurso do outro em "você fala como se ela fosse promíscua", entretanto, logo em seguida, temos: 
- [...] Estava à beira de um colapso. Eu é que acalmei a Bia. Fiquei umas duas horas segurando as mãos dela sem falar nada. Depois acarinhei ela um tempão. No dia seguinte, trepamos. A cura pelo sexo, esse é o meu método.

- Lá vem você de novo, fazendo o gênero obsceno, fescenino. Até parece que você transava com todas elas.

- Todas não, com algumas.

Os dois riram de novo (Kucinski, 2014d, p. 116).

O que poderia ser visto como censura, no riso conjunto se transforma em cumplicidade. Há muitas outras histórias recuperadas no conto, mas nos concentraremos em três últimas:

- Você parece só recordar os bons momentos. O fim do casarão foi melancólico. A Brenda se separou do Richard e voltou pra Inglaterra com a Mary pra morar com a mãe.

- Eu lembro. A gota d'água foi ela ter ido pro Rio fotografar a filhinha de uma presa política que estava com a avó. Era pra acalmar a mãe, que estava meio louca na prisão, achando que o bebê tinha sido sequestrado pelos milicos.

- E você lembra se deu certo?

- Disseram que deu. Mas o Richard reclamou que ela pensava mais nos filhos dos outros do que na filhinha deles (Kucinski, 2014d, p. 121-122).

Ao longo da conversa, os dois amigos trazem alguns episódios que mostram Brenda, uma jornalista estrangeira engajada na militância brasileira, como uma mulher preocupada com outras mulheres, especialmente com aquelas que, como ela, eram mães. Ela, por exemplo, se esforçou para conseguir documentação para a argentina Dolores e sua filha (Kucinski, 2014d, p. 114-115) e fez uma viagem de 14 horas de ônibus com Mary, sua própria filha que não tinha com quem ficar, para resgatar o filho, também criança, de um casal de argentinos que precisava de ajuda (Kucinski, 2014d, p. 119-121). Esse envolvimento com outras famílias seria a justificativa apresentada por Richard, o marido, para o divórcio. Entretanto, nas situações narradas, Brenda não apenas cuida constantemente da filha (tanto quanto possível em um contexto de clandestinidade, que, vale lembrar, é sempre perigoso), como também pontua que "Richard viajava muito" (Kucinski, 2014d, p. 120). Ou seja, o mesmo que se queixou de sua então esposa não ser uma mãe suficientemente presente era um pai ausente. Mas, de forma geral, é socialmente aceito que homens negligenciem os filhos em prol de obrigações, enquanto às mulheres é exigido que não sejam nada além de mães. Desse modo, percebe-se, nesse cenário, que mesmo em uma organização de esquerda, na qual, devido ao pensamento progressista, se poderia supor uma igualdade maior de gênero, as mulheres eram frequentemente vítimas de opressão.

Ainda sobre o momento de declínio do casarão, é rememorada brevemente a história de uma personagem denominada Bia, que encontra consonância com o que se passou com Imaculata, de "Sobre a natureza do homem":

- Eu também lembro que a Bia, com quem eu me dava melhor, entrou em depressão porque o pai reacionário continuou se recusando a falar com ela, mesmo depois de quase dois anos da sua volta do Chile. Muitas vezes flagrei a Bia chorando no quarto de empregada.

- Ela não se internou?

- Isso foi depois, quando ela recebeu uma notícia ruim sobre uma amiga dela que tinha ficado no Chile. A mãe e um dos irmãos da Bia foram ao casarão e levaram ela embora (Kucinski, 2014d, p. 122-123).

Bia também é afetada psicologicamente pelos anos de regime militar (depressão, internação). Diferente de Imaculata, entretanto, o que a afeta não é a violência diretamente sobre seu corpo, mas o que acontece com terceiros: o silêncio do pai e possivelmente a morte de uma amiga. Assim, percebe-se que o trauma pode ter origem nos mais diversos eventos e seu desdobramento se dá de diferentes formas.

Por fim, detenhamo-nos sobre a história de Mazé e Zé Eduardo:

- Não vá me dizer que você também teve um caso com a Mazé?

- Eu era vidrado nela, mas ela era do Zé Eduardo. O pessoal até chamava ela de Maria do Zé.

- Daí que veio o Mazé? 
- Eu que inventei o Mazé. Achei melhor. Maria do Zé passava a ideia de propriedade [...]. - Se eu bem me lembro, a Mazé engravidou do Zé Eduardo e depois houve algum problema.

- O problema foi que o grupo do Zé Eduardo proibia suas militantes de terem filhos. Mandaram a Mazé abortar, decisão do comando. [...] O que aconteceu foi que a Mazé não acatou a ordem, disse que não pertencia à organização, que nunca tinha pertencido, por isso não precisava se submeter. Então insinuaram que o Zé Eduardo engravidou a Mazé de propósito, pra abandonar a luta.

- Tiveram a coragem de fazer isso com o Zé Eduardo? Custo a acreditar.

- Pois acredite. Eu mesmo ouvi isso de alguns dirigentes. O Zé Eduardo, indignado, forçou a Mazé a abortar.

- E ela obedeceu?

- Obedeceu.

- Caramba. Aposto que os dois se arrependeram

- E muito. A Mazé nunca se recuperou (Kucinski, 2014d, p. 124-125).

O mesmo personagem que diz, criticamente, que "Maria do Zé passava a ideia de propriedade" parece não se dar conta de que essa noção de que a mulher pertence ao homem com quem se relaciona afetiva e sexualmente continua reproduzida em "ela era do Zé Eduardo", na própria alcunha "Mazé", que retira o possessivo "do", mas o mantém subentendido, assim como no questionamento ao final quanto a se a moça teria obedecido ao companheiro. O uso do verbo "obedecer" sugere que Zé Eduardo estaria em posição de autoridade em relação à Maria, autoridade reconhecida pelos dois personagens em diálogo, como se depreende das escolhas lexicais.

A concepção de que o corpo da mulher é propriedade de outrem é agravada em "o grupo do Zé Eduardo proibia suas militantes de terem filhos. Mandaram a Mazé abortar, decisão do comando". Um grupo que obriga a mulher ao aborto a viola tanto quanto o Estado que criminaliza a interrupção da gravidez, ambos os casos se configuram como tentativas de um controle externo sobre o corpo feminino. Surpreende ainda no trecho a empatia dos amigos para com Zé Eduardo, quando acusado de engravidar a moça de propósito para abandonar a organização ("Tiveram a coragem de fazer isso com o Zé Eduardo? Custo a acreditar!”), em comparação à ausência de emissão de juízo de valor no que concerne ao que foi feito à Maria. A violência contra a mulher, tão marcadamente presente nesse excerto, efetiva-se mais uma vez em "o Zé Eduardo, indignado, forçou a Mazé a abortar". O verbo "forçar" deixa claro que se tratava de uma imposição, que a mulher, contra a sua vontade, realizou um aborto. Não está dito se o método para levar ao aborto forçado foi exclusivamente persuasivo ou se incluiu agressão física. Em qualquer dos casos, trata-se de uma violência sobre a liberdade e sobre o corpo. $O$ poder que o comando tenta, sem sucesso, assegurar sobre o corpo de suas militantes é aquele que o homem, Zé Eduardo, tem certeza de possuir, pois a sua decisão, em um assunto que concernia ao casal, mas, antes de tudo, à mulher, foi cabal. Para a mulher, ficaram novamente os frutos dessa experiência de violência: Mazé, da mesma forma que Imaculata e Bia, nunca se recuperou.

Em entrevista à Revista Teresa, Rita Terezinha Schmidt observou que "A violência é proteica, assume múltiplas formas, mas está sempre alicerçada em uma pressuposição, a de que alguns seres humanos são menos humanos, ou de que algumas vozes ou protagonismos valem mais que outros" (2017, p. 251). A repetida violência direcionada a mulheres nos três contos de Bernardo Kucinski brevemente analisados sugere que na história brasileira, em tempos de ditadura e a ela posteriores, as figuras femininas têm sido desumanizadas, sobretudo por meio do controle de seus corpos. Partindo da afirmação de que "algumas vozes ou protagonismos valem mais que outros", é curioso notar que, em "Sobre a natureza do homem" e "Recordações do casarão", por mais que as mulheres sejam personagens centrais nos episódios narrados, essa recordação é elaborada por vozes masculinas, seja pela narração, como no primeiro texto, seja pelo diálogo, como no segundo. Estariam essas mulheres, traumatizadas, por demasiado sequeladas para que contassem suas próprias histórias? O que significa que tantas mulheres nunca tenham se recuperado e que, concomitantemente, homens que experenciaram o mesmo contexto histórico que elas não apenas narrem, mas assumam uma postura ativa frente à 
realidade conflituosa (como Rui em "Sobre a natureza do homem") e confraternizem e riam relembrando episódios dos momentos sombrios (como os dois amigos de "Recordações do casarão")? Ao permitir que essas questões sejam colocadas, os textos literários abrem possibilidades para se pensar histórias do Brasil diferentes daquela que vem sendo contada pelos documentos oficias, tantas vezes falsos, como visto. Mais de cinquenta anos se passaram desde o golpe à democracia brasileira e, ainda hoje, mesmo após os trabalhos da Comissão da Verdade, os arquivos militares não foram abertos, o que contribui para a continuidade de uma memória lacunar sobre o período. Maria Rita Kehl escreve:

Nesse "universo paralelo" das experiências não compartilhadas pela coletividade, experiências excluídas das práticas falantes e (consequentemente) da memória, vivem também, pelo menos parcialmente, os que tiveram seus corpos torturados nos subterrâneos da ordem simbólica ou sofreram a perda de amigos e parentes desaparecidos, vítimas de assassinatos nunca reconhecidos como tais por agentes de regimes autoritários. No Brasil, os opositores do regime militar que sobreviveram à tortura, embora circulem normalmente entre nós, vivem em um universo à parte não apenas em função da radicalidade da dor e da despersonalização que experimentaram, mas também porque as práticas infames dos torturadores nunca foram reconhecidas e reparadas publicamente. A sensação de irrealidade que acomete aqueles que passaram por formas extremas de sofrimento [...] fica então como que confirmada pela indiferença dos que se recusam a testemunhar o trauma (2010, p. 126).

Em uma realidade de silenciamento, alimentada em grande parte pela anistia concedida aos torturadores por ocasião do fim da ditadura militar, os contos de Kucinski, ficcionalmente, viabilizam a elaboração social e cultural do passado, passado este que se estende, permanecendo tanto nas vítimas que nunca se recuperaram, quanto nas instituições estatais burocráticas, violentas e negligentes frente à vida humana. Ainda, por meio dos mesmos textos, é possível pensar a violência de gênero que, nos casos estudados, imiscui-se às formas de violência do Estado, autoritário ou ausente, inclusive no espaço privado. As reflexões aqui suscitadas, ainda que não conclusivas, são importantes para que se pense a história de violência contra a mulher dentro da história de violência brasileira.

\section{Referências}

ARNS, Dom Paulo Evaristo (Org.) (1985). Brasil: nunca mais. Petrópolis, Rio de Janeiro: Editora Vozes.

BOURDIEU, Pierre (2014). A dominação masculina. Tradução de Maria Helena Kühner. Rio de Janeiro: BestBolso.

DAS, Veena (2007). Language and body. In: DAS, Veena. Life and words: violence and the descent into the ordinary. Califórnia: University of California Press. p. 38-58.

GASPARI, Elio (2011). A ditadura escancarada. São Paulo: Companhia das letras.

GINZBURG, Jaime (2012). Linguagem e trauma na escrita do testemunho. In: GINZBURG, Jaime. Crítica em tempos de violência. São Paulo: Edusp. p. 51-60.

GINZBURG, Jaime (2013). Literatura, violência e melancolia. Campinas: Autores associados.

KEHL, Maria Rita (2010). Tortura e sintoma social. In: TELES, Edson; SAFATLE, Vladimir (Org.). O que resta da ditadura: a exceção brasileira. São Paulo: Boitempo. p. 123-132.

KUCINSKI, Bernardo (2014a). Você vai voltar pra mim e outros contos. São Paulo: Cosac Naify.

KUCINSKI, Bernardo (2014b). Você vai voltar pra mim. In: KUCINSKI, Bernardo. Você vai voltar pra mime outros contos. São Paulo: Cosac Naify. p. 69-71.

KUCINSKI, Bernardo (2014c). Sobre a natureza do homem. In: KUCINSKI, Bernardo. Você vai voltar pra mim e outros contos. São Paulo: Cosac Naify. p. 43-56.

KUCINSKI, Bernardo (2014d). Recordações do casarão. In: KUCINSKI, Bernardo. Você vai voltar pra mim e outros contos. São Paulo: Cosac Naify. p. 111-125. 
KUCINSKI, Bernardo (2014e). K. Relato de uma busca. São Paulo: Cosac Naify.

MARCO, Valeria de (2004). A literatura de testemunho e a violência de Estado. Lua Nova, São Paulo, n. 62, p. 45-68. Disponível em: https:/ / bit.ly/330cNZS. Acesso em: 29 jul. 2014.

MICHAEL, Joachim (2017). Memória do desaparecimento: a ditadura no romance K. Relato de uma busca, de Bernardo Kucinski. Revista Teresa, São Paulo, n. 17, p. 15-30, abr. Disponível em: https://bit.ly/31Xhe01. Acesso em: 9 jul. 2017.

SCHMIDT, Rita Terezinha (2017). Entrevista concedida a Jaime Ginzburg em 2 de maio de 2016. Revista Teresa, São Paulo, n. 17, p. 251-264, abr. Disponível em: https://bit.ly/3jRT7OE. Acesso em: 9 jul. 2017.

VIEIRA, Beatriz de Moraes (2010). As ciladas do trauma: considerações sobre história e poesia nos anos 1970. In: TELES, Edson; SAFATLE, Vladimir (Org.). O que resta da ditadura: a exceção brasileira. São Paulo: Boitempo. p. 151-176. 